PROFESSOR PAOLO VERCELLINI (Orcid ID : 0000-0003-4195-0996)

Article type : State-of-the-art review

\title{
Medical treatment in the management of deep endometriosis infiltrating the proximal rectum and sigmoid colon: a comprehensive literature review
}

Running headline: Medical therapy for bowel endometriosis

Paolo Vercellini ${ }^{1,2}$, Laura Buggio ${ }^{2}$, Alessandra Borghi ${ }^{1}$, Ermelinda Monti ${ }^{2}$, Umberto Gattei $^{2}$ \& Maria Pina Frattaruolo ${ }^{2}$

${ }^{1}$ Department of Clinical Sciences and Community Health, University of Milan, Milan, ${ }^{2}$ IRCCS Ca 'Granda Foundation - Maggiore Policlinico Hospital, Milan, Italy

\section{Correspondence}

Paolo Vercellini

Department of Clinical Sciences and Community Health, Università degli Studi di Milano and Fondazione Istituto di Ricovero e Cura a Carattere Scientifico Ca' Granda Ospedale Maggiore Policlinico, Via Commenda, 12 - 20122 Milan, Italy e-mail: paolo.vercellini@unimi.it

\section{Conflict of interest statement:}

All the authors declare that they have no conflicts of interest.

This article has been accepted for publication and undergone full peer review but has not been through the copyediting, typesetting, pagination and proofreading process, which may lead to differences between this version and the Version of Record. Please cite this article as doi: 10.1111/aogs.13328

This article is protected by copyright. All rights reserved. 


\title{
Abstract
}

A comprehensive literature review was performed to evaluate the effect of various hormonal therapies, in terms of variations of intestinal and pain complaints and of patient satisfaction with treatment, in women with symptomatic, non-severely sub-occlusive endometriosis infiltrating the proximal rectum and sigmoid colon. A MEDLINE search through PubMed from 2000 to 2018 was conducted to identify all original English language articles published on medical treatment for colorectal endometriosis. Additional reports were identified by systematically reviewing reference lists and using the "similar articles" function in PubMed. A total of 420 women with colorectal endometriosis treated with combined oral contraceptives, progestins, gonadotropin releasinghormone ( $\mathrm{GnRH}$ ) agonists, and aromatase inhibitors have been described in eight case series, two retrospective cohort studies, and four case reports. Published data consistently suggest that several hormonal medications can control most symptoms associated with intestinal endometriosis, provided the relative bowel lumen stenosis is less than $60 \%$. Patients with irritative-type symptoms appear to respond better than those with constipation. Overall, about two thirds of women were satisfied with the treatment received, independently of the drug used. Progestins are the compound supported by the largest body of evidence. The addition of aromatase inhibitors or, alternatively, the use of GnRH agonists, do not seem to be associated with better outcomes. Long-term treatment with a progestin should be proposed as an alternative to surgery to patients with non-severely subocclusive endometriosis infiltrating the proximal rectum and sigmoid colon not seeking conception. The final decision should be shared together with the woman, respecting her preferences and priorities.

\section{Key words:}

endometriosis; bowel endometriosis; colorectal endometriosis; pelvic pain; medical therapy; oral contraceptives; progestins.

\author{
Abbreviations \\ $\mathrm{GnRH}$ = gonadotropin releasing-hormone; \\ NETA = nor-ethisterone acetate; \\ $\mathrm{OC}=$ oral contraceptive
}

This article is protected by copyright. All rights reserved. 


\section{Key message}

According to the findings of case series and cohort studies, low-dose estrogen-progestins and progestins relieved intestinal symptoms in around two thirds of women with non-severely subocclusive colorectal endometriosis, thus constituting an alternative to surgery in selected women not seeking conception.

\section{Introduction}

Deep bowel endometriosis, i.e., endometriosis infiltrating the intestinal muscular layer (1), appears to affect about one tenth of women with the endometriotic disease $(2,3)$. When endometriosis causes bowel obstruction or severe sub-occlusion, surgery is the only reasonable choice. However, most patients with deep bowel endometriosis complains of cyclic and non-cyclic symptoms, such as abdominal bloating, intestinal cramping, diarrhea, and constipation, without obvious obstruction to stool passage (Figures 1 and 2). Symptoms may be associated not only with the degree of endometriotic infiltration and bowel lumen restriction, but also with lesion localization $(1,4)$. The rectosigmoid colon is the most frequently involved intestinal tract, followed by isolated nodules of the proximal sigmoid, and by lesions of the terminal ileus and cecum $(3,5,6)$.

According to some authors, excisional surgery is the best solution for women with symptomatic intestinal endometriosis, as medical treatments may exert an effect on the endometrial and smooth muscle component of the nodule, but not on the extensive fibrotic component, thus providing limited benefit $(3,7-9)$. However, several investigators observed substantial improvements of bowel symptoms during hormonal treatment (10-14). Disentangling the uncertainties on the role of medical therapy in women with infiltrating bowel endometriosis seems exceedingly important, as excisional procedures with opening of the bowel lumen are generally effective in relieving intestinal symptoms, but are also associated with severe short- and long-term complications in about one patient out of 10 (e.g., intestinal leakage, anastomosis dehiscence, septic peritonitis, rectovaginal fistula formation, bowel anastomosis stenosis, iatrogenic neurologic bladder dysfunction with need for long periods of self-catheterization, and postoperative constipation and de-novo rectal dysfunction) (16-25). The incidence of some complications is associated also with the distance between the lower margin of resection and the anal verge $(9,26)$. Thus, defining the localization of the lesion is important for limiting selection bias when comparing treatments in a research setting, and for counselling women when taking a decision in a clinical setting $(9,15-$ $20,26,27)$.

This article is protected by copyright. All rights reserved. 
Given this background and the lack of consensus regarding the role of hormonal treatments for bowel endometriosis, we deemed opportune to synthetize the available evidence on the outcome of various medical therapies that have been used in patients with symptomatic, nonseverely sub-occlusive lesions. As hormonal treatments for endometriosis generally suppress ovulation (28), the findings presented in this review may be used to inform and counsel specifically women not seeking conception.

\section{Material and methods}

The objective of the present comprehensive review was the evaluation of the effect of various hormonal therapies, in terms of variations of intestinal and pain complaints as well as of patient satisfaction with treatment, in women with symptomatic colorectal endometriosis.

The aim was to identify reports of studies including patients with an instrumental diagnosis of endometriosis infiltrating the muscular layer of the proximal rectal tract $(\geq 8 \mathrm{~cm}$ from the anal verge), the rectosigmoid junction (13 to $15 \mathrm{~cm}$ from the anal verge) and the sigmoid ( $>15 \mathrm{~cm}$ from the anal verge). Studies focusing specifically on nodules of the distal rectum (within $8 \mathrm{~cm}$ from the anal verge) were not considered, as these lesions constitute part of rectovaginal endometriotic plaques (29). Stenotic occlusion of the rectal ampulla is exceedingly rare, due to its large caliber and distensibility. Moreover, differently from the proximal third of the rectum (upper rectum), the midrectum, that corresponds to the Douglas' pouch, only has an anterior peritoneal covering. This renders sharp angulation, a determinant of bowel occlusion caused by endometriosis, mechanically unlikely if not impossible (15). In addition, the symptoms associated with endometriotic nodules of the mid- low-rectum are dyschezia and tenesmus, which are specific of lesions of the ampulla (30). Owing to the clinical differences with other endometriotic lesions of the proximal large bowel tract, the effect of medical therapies on nodules of the distal rectum has been already reported separately in another review (31).

A MEDLINE search through PubMed from January 2000 to January 2018 was conducted using combinations of medical subject heading terms "colorectal endometriosis", "intestinal endometriosis", "bowel endometriosis", "medical treatment", "combined oral contraceptives", "progestins", "GnRH agonists", "danazol", and "aromatase inhibitors". Only articles written in English and published in peer-reviewed journals were included, and the relative reference lists were systematically reviewed in order to identify further reports. Additional articles were searched using the "similar articles" function in PubMed. Information was extracted on study design, number of

This article is protected by copyright. All rights reserved. 
treated patients, type of intestinal lesions, type of hormonal drugs used, treatment period, adverse events, types of questionnaires administered to assess bowel symptoms and function, and overall clinical outcome.

\section{Results}

A total of 420 women with large bowel endometriosis treated with combined oral contraceptives $(\mathrm{OC})$, progestins, gonadotropin releasing-hormone $(\mathrm{GnRH})$ agonists, and aromatase inhibitors have been described in 14 articles published in the period 2000-2018. Eight studies were case series (seven prospective, one retrospective) (10-14,32-34), two were retrospective cohort studies $(29,35)$, and four were case reports (36-39) (Table 1). The precise location of lesions has not been systematically specified, and sometimes what was exactly intended with "colorectal endometriosis" is unclear. This terminology appears to have been used for different clinical situations, and not exclusively in cases of sigmoid and recto-sigmoid junction endometriosis, but also in cases of rectal nodules, which should be more properly included in the category of rectovaginal lesions or Douglas pouch lesions infiltrating the anterior rectal wall $(15,29,31)$. The duration of medical treatment was three months in two studies, six months in three, 12 months in five, and $>12$ months in four, including the two cohort studies.

\section{Estrogen-progestins and progestins}

Ferrari et al. (12) treated 26 patients with colorectal endometriotic lesions infiltrating the tunica muscularis with a low-dose, monophasic OC used continuously for 12 months. The lesion, as assessed at rectal endoscopic ultrasonography, was within $5 \mathrm{~cm}$ from the anal rim in 4 cases, between 5 and $10 \mathrm{~cm}$ in 14, and above $10 \mathrm{~cm}$ in eight. Women with an intestinal lumen stenosis more than $50 \%$ were excluded. Symptoms progressively improved and the nodule volume decreased by $62 \%$ at the end of the study. At 1-year evaluation, 18 patients (69\%) were satisfied or very satisfied with their treatment, four were uncertain, and four were dissatisfied or very dissatisfied. Millochau et al. (38) reported the case of a woman treated with estrogen-progestin combinations for an isolated nodule of the sigmoid colon that grew during a 4-year medical treatment causing occlusive symptoms and necessitating surgery.

Egekvist et al. (35) conducted a retrospective cohort study in one of the two Danish tertiary referral centers in which treatment of advanced endometriosis is allowed by the national health authority. Patients treated medically or surgically for rectosigmoid lesions were identified in the electronic patient record system according to ICD10 codes for endometriosis affecting the rectosigmoid, vagina or the rectovaginal septum. Of the 238 women with rectosigmoid

This article is protected by copyright. All rights reserved. 
endometriosis verified by transvaginal ultrasonography and/or magnetic resonance imaging, 78 (33\%) underwent immediate surgery, whereas 160 were treated medically with OCs, a levonorgestrel-releasing- intra-uterine device, or oral progestins. After a median follow-up of 22 months, 27 of the 160 (17\%) patients initially treated medically necessitated surgery. Overall, 133/238 (56\%) women with rectosigmoid endometriosis could be managed successfully with hormone manipulation, and about four out of five women (133/160; 83\%) for whom a medical treatment was decided at baseline evaluation, eventually avoided surgery.

The largest evidence on the effect of progestins for bowel endometriosis is derived from studies on the use of nor-ethisterone acetate (NETA) and dienogest. Ferrero et al. (11) enrolled 40 patients with nodules infiltrating the sigmoid $(n=18)$, the recto-sigmoid junction $(n=12)$, and the rectum $(n=10)$. The diagnosis was based on multidetector computed tomography enteroclysis, and women with of a stenosis of the bowel lumen greater than $60 \%$ were excluded. Nor-ethisterone acetate determined relief from symptoms related to the menstrual cycle, including constipation, diarrhea, and cyclical rectal bleeding. The severity of diarrhea, intestinal cramping and passage of mucus also significantly improved during treatment. However, progestin therapy did not substantially ameliorate constipation, abdominal bloating and feeling of incomplete evacuation after bowel movements. Overall $21 / 40$ patients $(53 \%)$ referred some improvement in gastrointestinal symptoms. At 1-year evaluation, $60 \%$ of participant were satisfied or very satisfied with their treatment, $20 \%$ were uncertain, and $20 \%$ were either dissatisfied or very dissatisfied.

The effect of dienogest in patients with bowel endometriosis was assessed by the same research group in two case series. Yela et al. (13) treated 16 women with rectovaginal or bowel endometriosis with dienogest, $2 \mathrm{mg} /$ day for six months. All participants had already used other progestins without improvement of pain. It is unclear whether all the participants had intestinal lesions and which was the exact lesion location. The mean volume of the intestinal nodule decreased from $3.4 \mathrm{cc}$ at baseline to $1.6 \mathrm{cc}$ at the end of treatment. A significant reduction in defecation pain, referred by $69 \%$ of the patients at baseline, was observed from the second month of therapy.

Leonardo-Pinto et al. (14) evaluated the effect of dienogest prescribed for 12 months in 30 women with rectovaginal and bowel endometriosis. At baseline, participants referred persistent pain complaints despite medical treatment with other progestins for at least six months. Also in this case, whether all the patients had intestinal lesions and at which level was not specified. Intestinal pain decreased significantly during the study period but, at odds with their previous experience (35), the authors did not observe a significant reduction in bowel lesions size.

This article is protected by copyright. All rights reserved. 
Dienogest was used also by Tamura et al. (37) and Ng et al. (39) in two women with endometriosis located at the proximal rectum and rectosigmoid junction. Substantial bowel symptom improvement and lesion size reduction were observed in both patients after, respectively, 22- and six-month progestin treatment.

A parallel cohort study was conducted on 87 women with colorectal endometriosis not causing persistent and severe sub-occlusive symptoms, to investigate whether an OC or a progestin are a satisfactory alternative to surgery in women who choose their treatment after a standardized shared decision-making process (29). A total of 50 patients chose treatment with a low-dose, monophasic OC ( $n=12$ ) or a progestin (nor-ethisterone acetate, $2.5 \mathrm{mg} /$ day or dienogest, $2 \mathrm{mg} /$ day; $n=38$ ), whereas 37 women confirmed their previous indication to surgery. Six women in the medical treatment group requested surgery because of drug inefficacy or intolerance. Seven major complications (19\%) were observed in the surgery group. At 12-month follow-up, 39 (78\%) women in the OC/progestin group were satisfied with their treatment, compared with $28(76 \%)$ in the surgery group (intention-to-treat analysis). Corresponding figures after a median follow-up of, respectively, 40 and 45 months, were $72 \%$ in the former group and $65 \%$ in the latter one. The 60 -month cumulative proportion of dissatisfaction-free participants was $71 \%$ in the OC/progestin group compared with $61 \%$ in the surgery group. Bowel symptoms were improved by both treatments.

\section{GnRH agonists}

Porpora et al. (36) treated with leuprolide acetate in a monthly depot formulation, a woman with sigmoid endometriosis and observed symptom remission and lesion disappearance at 6-month follow-up colonoscopy.

The effect of a GnRH agonist (triptorelin in a depot 3-monthly formulation) with add-back therapy (oral tibolone, $2.5 \mathrm{mg} /$ day) for 12 months was assessed by Ferrero et al. (10) in 18 women with endometriotic nodules infiltrating the sigmoid $(n=9)$, the recto-sigmoid junction $(n=5)$, and the rectum $(n=4)$. The larger colorectal nodule had a mean diameter of $2.2 \pm 0.6 \mathrm{~cm}$ and the mean degree of stenosis of the bowel lumen was $42.0 \% \pm 9.7 \%$. Intestinal symptoms improved during treatment in 11 (61\%) women, whereas in 7 (39\%) the intestinal function did not change. In particular, patients with symptoms mimicking diarrhea-predominant irritable bowel syndrome benefitted more from $\mathrm{GnRH}$ agonist treatment compared with those complaining of symptoms mimicking constipation-predominant irritable bowel syndrome. In fact, abdominal bloating, intestinal cramping, and passage of mucus improved, but feeling of incomplete evacuation did not vary. At 1-year evaluation, 13 (72\%) women were satisfied with their treatment.

This article is protected by copyright. All rights reserved. 
Roman et al. (34) evaluated the effect of one i.m. depot injection of triptorelin $11.25 \mathrm{mg}$ plus one daily dose of percutaneous estradiol $0.1 \%$ as a preoperative measure in 70 patients with an endometriotic rectal nodule infiltrating at least the muscular layer and up to $15 \mathrm{~cm}$ above the anus. The rectal lesions were identified at endo-rectal ultrasonography, and a computed tomographybased virtual colonoscopy was performed to identify bowel lumen stenosis and additional intestinal tract localizations. After three months of therapy, cyclic digestive complaints were relieved in more than half of the women (defecation pain, 57\%; abnormal frequency of bowel movements, $43 \%$; bloating, 36\%), whereas constipation and non-cyclic symptoms were improved in less than a third of patients. Subjective improvement was unrelated with rectal nodule volume.

\section{Aromatase inhibitors}

An aromatase inhibitor was used by Ferrero et al. (32) in six women with bowel nodules infiltrating at least the tunica muscularis, but with lumen stenosis less than $60 \%$. Four patients complained of intestinal cramping, three of abdominal bloating, three of symptoms mimicking irritable bowel syndrome (e.g., diarrhea), two of constipation, two of passage of mucus in the stools, and one of cyclic rectal bleeding. The patients received oral letrozole $(2.5 \mathrm{mg} /$ day) combined with NETA ( 2.5 $\mathrm{mg} /$ day) to prevent ovarian stimulation. All symptoms improved during the 6-month treatment, except constipation. At final assessment, four women (67\%) were satisfied with the treatment received and declared that gastrointestinal symptoms were improved.

\section{Discussion}

Compared with superficial peritoneal endometriosis, deep endometriosis has a distinct histological characteristic as, in addition to the ectopic endometrial-like mucosa (endometrial epithelium and stroma), and the fibrotic component deriving from inflammation (caused by the metabolic activity of the ectopic endometrium and repeated micro-hemorrhages), smooth muscle fibers are also present (44). This is expected because the so-called deep endometriosis infiltrates the wall of hollow viscera such as the bowel, the bladder, the ureter, and the vagina. The result is a sort of desmoplastic lesion in the form of nodules or plaques comprising the three constituents, the mucosal, the fibrotic, and the smooth muscular one (44). If the smooth muscular component is the histologic hallmark of deep endometriosis, we consider as "deep" those forms of bowel endometriosis that infiltrate at least the muscular layer of the considered intestinal tract (1).

This article is protected by copyright. All rights reserved. 
Responsiveness to gonadal steroids of the endometrium within deep bowel lesions is the prerequisite for medical therapy aimed at inducing metabolic quiescence of ectopic glands. Noël et al. demonstrated that progesterone receptors were present in major histologic components of colon endometriosis, including the smooth muscle fibers (45). Thus, hormonal treatments should exert an effect on two out of the three components of deep endometriosis, that is, the ectopic endometrial mucosa, and the smooth muscle fibers infiltrated by it. On the other hand, a major effect of medical therapies on the fibrotic component appears unlikely, although an influence of progestins on fibrosis remodeling during time cannot be excluded, due to their demonstrated anti-inflammatory properties $(46,47)$.

Two pathogenic mechanisms explain pain associated with deep endometriotic lesions, i.e., chronic inflammation deriving from the metabolic activity of ectopic endometrium, and secondary fibrosis with embedding of endometriotic glands into scar tissue $(15,30)$. Recurring release of mediators of inflammation, such as prostaglandins and cytokines, may cause a functional-type, mostly cyclic pain, such as irritative-type intestinal symptoms, whereas occlusive-type intestinal symptoms are generally the mechanical consequence of fibrotic tissue retraction, but they may be influenced also by inflammatory changes of bowel wall nodules $(3,6,7)$.

Overall, the quality of the evidence on the effect of hormonal therapies as an alternative to surgery for symptomatic bowel endometriosis is suboptimal. Mainly non-comparative studies are available. Moreover, diverse compounds or combination of compounds have been used with very different durations of treatment. The exact location of intestinal endometriosis was not systematically indicated. Outcomes have been measured using different questionnaires and scales, thus rendering comparisons difficult. Scoring systems to measure pelvic dysfunction and quality of life in women with endometriosis should be standardized (48). Good-quality, comparative effectiveness research is seriously needed to more precisely define the respective impact of medical treatment and extirpative surgery in the long-term management of patients with symptomatic bowel endometriosis. In the words of Riiskjær et al. (48) "the indication for surgery in bowel endometriosis is almost always relative" and "this makes selection of indications for surgery and comparison of treatment modalities and results important".

To this aim, randomized, controlled trials may appear preferable, but adequately designed, prospective parallel cohort studies may also be conducted, especially when women are not prone to receive randomly such diverse treatments, and prefer to take part in the medical decision by choosing their preferred alternative based on their priorities after detailed and impartial information $(29,49)$. In fact, the two options cannot be put on the same level, because the respective balances

This article is protected by copyright. All rights reserved. 
between potential benefits and potential harms are hardly comparable in the absence of severe subocclusion, thus questioning the therapeutic equipoise that is ethically needed for randomization. On the other hand, the shared decision-making may be unduly influenced by physician's empathy, own beliefs, and a priori conviction, thus potentially undermining the scientific foundation on which the process should be based.

In everyday practice the real query may not be which of the two treatments is more effective in absolute terms, but instead to what extent a satisfactory improvement of bowel symptoms is achievable with medical therapy when surgery is considered the standard treatment and, consequently, which is the probability of undergoing surgery anyway because of failure of hormonal manipulation. In this regard, the cohort studies by Egekvist et al. (35) and Vercellini et al. (29) are encouraging, as the majority of patients who used hormonal medications on a long-term basis eventually avoided surgery and were satisfied with their treatment as pain and bowel symptoms substantially improved.

In spite of the limited quantity and quality of the findings provided in published reports, and while waiting for future better-designed studies, the data included in the present review constitute the only available evidence on which patients and caring gynecologists can base their shared decisions now. Medical treatment for bowel endometriosis may constitute a therapeutic alternative when established intestinal fibrotic stenosis with severely sub-occlusive symptoms are absent $(2,3,6)$. Bowel occlusion is likely when wall infiltration is associated with intestinal fixed, strict angulation, or when the lumen is intrinsically narrow, such as in cases of involvement of the last ileal loop and the ileocecal valve $(50,51)$. The practical issue here is defining when medical therapy is advantageous over surgery, taking into consideration that, if chosen, hormonal treatments should be continued for many years, as drugs control endometriosis but do not definitively cure it $(28,31)$. In this regard, the untoward effects of different medications should be adequately described. As an example, progestins are frequently associated with bloating, weight gain, and irregular bleeding, especially in women with uterine adenomyosis. This may adversely impact on treatment adherence and, on the long term, induce patients to request surgery. This important aspect must be clarified during counseling, together with the fact that also conservative surgery as an isolated measure does not guarantee definitive symptoms relief $(19,20,52)$.

Published data consistently suggest that several hormonal medications can control most symptoms associated with colorectal endometriosis, provided the relative bowel lumen stenosis is less than $60 \%(10-12,29,32)$. In particular, patients with irritative-type symptoms appear to respond significantly better than those with constipation, which may originate also from altered innervation.

This article is protected by copyright. All rights reserved. 
The resolution of cyclic inflammation due to intra- and peri-lesional micro-hemorrhages may explain the effect on irritative complaints, whereas the observed decrease in nodule size under medical treatment may partially relieve the reduction in lumen caliber of the affected bowel tract. Overall, about two thirds of women were satisfied with the treatment received, independently of the drug used. Progestins are the compound supported by the largest body of evidence. The addition of aromatase inhibitors or, alternatively, the use of GnRH agonists, do not seem to be associated with better outcomes. Given the similar efficacy of the various drugs evaluated in women with colorectal endometriosis, priority should be given to safety, tolerability, and costs when choosing among different medical alternatives. In this regard, progestins appear to offer the best overall therapeutic profile, especially considering that medications may be used for very long periods of time.

Recently Casper questioned the role of OCs in the management of endometriosis based on the hypothesis that, owing to the supra-physiologic estrogen content, these combinations may not adequately suppress lesions and control symptoms (46). Although some literature data suggest that OCs may be safely used in women with colorectal endometriosis $(12,29)$, bowel occlusion during treatment with estrogen-progestin combinations has been reported (38). Therefore, when treating women with symptomatic intestinal endometriosis, it may be wiser to use progestin monotherapies rather than OCs in order to minimize the risk of occlusion, (31). An algorithm for the management of non-occlusive colorectal endometriosis is suggested (Figure 3), based on the idea that, in women not seeking a natural conception, medical treatment may be considered as the first line of treatment, with surgery reserved to those patients not responding to, not tolerating, or with contraindications to progestins.

Medical therapy must be evaluated with caution when managing women who will seek a conception in the short term. In fact, some cases of large bowel occlusion or perforation as well as hydroureteronephrosis have been reported during pregnancy (53-55). Thus, the hormonal milieu of gestation may not guarantee the same lesion control usually observed during medical treatment. Surgery should be discussed also before undertaking in-vitro fertilization, as similar complications have been observed during ovarian stimulation $(56,57)$. Abdominal procedures for complicated colorectal endometriosis in presence of a gravid uterus may reveal technically demanding and risky for both the mother and the fetus $(58,59)$. Thus, women with sub-occlusive forms seeking pregnancy in the future should be thoroughly informed about the risks of not undergoing prior bowel surgery, and should be referred to tertiary care endometriosis centers where expert abdominal surgeons are available for pre-conception evaluation and advice. Unfortunately, except bowel occlusion, there is

This article is protected by copyright. All rights reserved. 
currently no robust evidence demonstrating that prophylactic surgery reduces substantially the risk of other major complications during in-vitro fertilization and pregnancy.

In conclusion, long-term treatment with a progestin should always be included among the therapeutic options for women with non-severely sub-occlusive bowel endometriosis not seeking a conception. Given the dramatically different safety profiles, medical treatment and surgery may not be proposed as an "either/or" decision, but rather as a "step-up" decision, where surgery may be indicated as a second step only in those patients not responding to, not tolerating, or with contraindications to progestins. Women should be informed in detail about the potential benefits and potential harms of undergoing surgical removal of intestinal endometriosis and of attempting long-term lesion and symptom control with medical therapies (60). The final decision should be shared together with the woman, respecting her preferences and priorities.

\section{Funding}

This article was financed by Italian fiscal contribution "5×1000" 2012 - Ministero dell'Istruzione, dell'Università e della Ricerca - devolved to Fondazione Istituto di Ricovero e Cura a Carattere Scientifico Ca' Granda Ospedale Maggiore Policlinico, Milano, Italy.

\section{REFERENCES}

1. Chapron C, Chopin N, Borghese B, Foulot H, Dousset B, Vacher-Lavenu MC, et al. Deeply infiltrating endometriosis: pathogenetic implications of the anatomical distribution. Hum Reprod. 2006;21:1839-45.

2. Koninckx PR, Ussia A, Adamyan L, Wattiez A, Donnez J. Deep endometriosis: definition, diagnosis, and treatment. Fertil Steril. 2012;98:564-71.

3. Abrao MS, Petraglia F, Falcone T, Keckstein J, Osuga Y, Chapron C. Deep endometriosis infiltrating the recto-sigmoid: critical factors to consider before management. Hum Reprod Update. 2015;21:329-39.

4. Roman H, Ness J, Suciu N, Bridoux V, Gourcerol G, Leroi AM, et al. Are digestive symptoms in women presenting with pelvic endometriosis specific to lesion localisations? A preliminary prospective study. Hum Reprod. 2012;27:3440-9.

This article is protected by copyright. All rights reserved. 
5. Vercellini P, Chapron C, Fedele L, Gattei U, Daguati R, Crosignani PG. Evidence for asymmetric distribution of lower intestinal tract endometriosis. BJOG. 2004;111:1213-7.

6. Nezhat C, Li A, Falik R, Copeland D, Razavi G, Shakib A, et al. Bowel endometriosis: diagnosis and management. Am J Obstet Gynecol. 2017;pii: S0002-9378(17)31180-8.

7. Remorgida V, Ferrero S, Fulcheri E, Ragni N, Martin DC. Bowel endometriosis: presentation, diagnosis, and treatment. Obstet Gynecol Surv. 2007;62:461-470.

8. Minelli L, Fanfani F, Fagotti A, Ruffo G, Ceccaroni M, Mereu L. Laparoscopic colorectal resection for bowel endometriosis: feasibility, complications, and clinical outcome. Arch Surg. 2009;144:234-9.

9. Milone M, Vignali A, Milone F, Pignata G, Elmore U, Musella M, et al. Colorectal resection in deep pelvic endometriosis: Surgical technique and post-operative complications. World J Gastroenterol. 2015;21:13345-51.

10. Ferrero S, Camerini G, Ragni N, Menada MV, Venturini PL, Remorgida V. Triptorelin improves intestinal symptoms among patients with colorectal endometriosis. Int J Gynecol Obstet. 2010;108:250-1.

11. Ferrero S, Camerini G, Ragni N, Venturini PL, Biscaldi E, Remorgida V. Norethisterone acetate in the treatment of colorectal endometriosis: a pilot study. Hum Reprod. 2010;25:94-100.

12. Ferrari S, Persico P, DI Puppo F, Vigano P, Tandoi I, Garavaglia E, et al. Continuous low-dose oral contraceptive in the treatment of colorectal endometriosis evaluated by rectal endoscopic ultrasonography. Acta Obstet Gynecol Scand. 2012;91:699-703.

13. Yela DA, Kajikawa P, Donati L, Cursino K, Giraldo H, Laguna Benetti-Pinto C. Deep infiltrating endometriosis treatment with dienogest: a pilot study. J Endometriosis Pelvic Pain Disorders 2015;7: 33-7.

14. Leonardo-Pinto JP, Benetti-Pinto CL, Cursino K, Yele DA. Dienogest and deep infiltrating endometriosis: The remission of symptoms is not related to endometriosis nodule remission. Eur J Obstet Gynecol Reprod Biol. 2017; 211:108-11.

15. Vercellini P, Carmignani L, Rubino T, Barbara G, Abbiati A, Fedele L. Surgery for deep endometriosis: a pathogenesis-oriented approach. Gynecol Obstet Invest. 2009;68:88-103.

This article is protected by copyright. All rights reserved. 
16. Vercellini P, Crosignani PG, Abbiati A, Somigliana E, Viganò P, Fedele L. The effect of surgery for symptomatic endometriosis: the other side of the story. Hum Reprod Update. 2009; 15: 177-188.

17. De Cicco C, Corona R, Schonman R, Mailova K, Ussia A, Koninckx P. Bowel resection for deep endometriosis: a systematic review. BJOG. 2011; 118: 285-91.

18. Kondo W, Bourdel N, Tamburro S, Cavoli D, Jardon K, Rabischong B, Botchorishvili R, Pouly J, Mage G, Canis M. Complications after surgery for deeply infiltrating pelvic endometriosis. BJOG. 2011; 118: 292-298.

19. Roman H, Bridoux V, Tuech JJ, Marpeau L, da Costa C, Savoye G, et al. Bowel dysfunction before and after surgery for endometriosis. Am J Obstet Gynecol. 2013;209:524-30.

20. Roman H, Vassilieff M, Tuech JJ, Huet E, Savoye G, Marpeau L, et al. Postoperative digestive function after radical versus conservative surgical philosophy for deep endometriosis infiltrating the rectum. Fertil Steril. 2013;99:1695-704.

21. Trencheva K, Morrissey KP,Wells M. Identifying important predictors for anastomotic leak after colon and rectal resection: prospective study on 616 patients. Ann Surg. 2013;257:108-113.

22. Possover M. Pathophysiologic explanation for bladder retention in patients after laparoscopic surgery for deeply infiltrating rectovaginal and/or parametric endometriosis. Fertil Steril. 2014;101:754-8.

23. Tarjanne S, Ng CH, Manconi F, Arola J, Mentula M, Maneck B, et al. Complications and longterm follow-up on colorectal resections in the treatment of deep infiltrating endometriosis extending to bowel wall. Acta Obstet Gynecol Scand. 2015;94:72-9.

24. Bouaziz J, Soriano D. Complications of colorectal resection for endometriosis. Minerva Ginecol. 2017; 69:477-487.

25. Iversen ML, Seyer-Hansen M, Forman A. Does surgery for deep infiltrating bowel endometriosis improve fertility? A systematic review. Acta Obstet Gynecol Scand. 2017;96:688-693.

26. Ret Davalos ML, De Cicco C, D'Hoore A, De DB, Koninckx PR. Outcome after rectum or sigmoid resection: a review for gynecologists. J Minim Invasive Gynecol. 2007;14:33-8.

27. Abrão MS, Borrelli GM, Clarizia R, Kho RM, Ceccaroni M. Strategies for Management of Colorectal Endometriosis. Semin Reprod Med. 2017; 35:65-71.

This article is protected by copyright. All rights reserved. 
28. Vercellini P, Buggio L, Berlanda N, Barbara G, Somigliana E, Bosari S. Estrogen-progestins and progestins for the management of endometriosis. Fertil Steril. 2016;106:1552-1571.e2.

29. Vercellini P, Frattaruolo MP, Rosati R, Dridi D, Roberto A, Mosconi P, et al. Medical treatment or surgery for colorectal endometriosis? Results of a shared decision-making approach. Hum Reprod. 2018;33(2):202-211.

30. Vercellini P. Endometriosis: what a pain it is. Semin Reprod Endocrinol. 1997;15:251-61.

31. Vercellini P, Buggio L, Somigliana E. Role of medical therapy in the management of deep rectovaginal endometriosis. Fertil Steril. 2017;108:913-930.

32. Ferrero S, Camerini G, Ragni N, Venturini PL, Biscaldi E, Seracchioli R, et al. Letrozole and norethisterone acetate in colorectal endometriosis. Eur J Obstet Gynecol Reprod Biol. 2010;150:199202.

33. Harada M, Osuga $\mathrm{Y}$, Izumi G, Takamura M, Takemura $\mathrm{Y}$, Hirata $\mathrm{T}$, et al. Dienogest, a new conservative strategy for extragenital endometriosis: a pilot study. Gynecol Endocrinol. 2011;27:71720.

34. Roman H, Saint-Ghislain M, Milles M, Marty N, Hennetier C, Moatassim S, et al. Improvement of digestive complaints in women with severe colorectal endometriosis benefiting from continuous amenorrhoea triggered by triptorelin. A prospective pilot study. Gynecol Obstet Fertil. 2015;43:575-81.

35. Egekvist AG, Marinovskij E, Forman A, Kesmodel US, Riiskjaer M, Seyer-Hansen M. Conservative approach to rectosigmoid endometriosis: a cohort study. Acta Obstet Gynecol Scand. 2017; 96: 745-750.

36. Porpora MG, Pallante D, Ferro A, Crobu M, Cerenzia P, Panici PL. Intestinal endometriosis without evident pelvic foci treated with gonadotropin-releasing hormone agonist. Eur J Obstet Gynecol Reprod Biol. 2006;125:265-6.

37. Tamura R, Tsuneki I, Yanase T. Effectiveness of the cyclic administration of dienogest in a case of pathological disappearance of intestinal endometriosis. Int J Women Health. 2013;5:421-4.

38. Millochau JC, Abo C, Darwish B, Huet E, Dietrich G, Roman H. Continuous amenorrhea may be insufficient to stop the progression of colorectal endometriosis. J Minim Invasive Gynecol. 2016;23:839-42.

This article is protected by copyright. All rights reserved. 
39. Ng BK, Phon SE, Zainuddin AA, Ng WYL, Abd Shukor N, Lim PS. Bowel endometriosis: a diagnostic and therapeutic challenge. Horm Mol Biol Clin Investig. 2017 Sep 6. pii: /j/hmbci.aheadof-print/hmbci-2017-0051/hmbci-2017-0051.xml. doi: 10.1515/hmbci-2017-0051. [Epub ahead of print].

40. Eypasch E, Williams JI, Wood-Dauphinee S, Ure BM, Schmülling C, Neugebauer E, et al. Gastrointestinal Quality of Life Index: development, validation and application of a new instrument. Br J Surg. 1995;82:216-22.

41. Lewis SJ, Heaton KW. Stool form scale as a useful guide to intestinal transit time. Scand J Gastroenterol. 1997;32:920-4.

42. Knowles CH, Eccersley AJ, Scott SM, Walker SM, Reeves B, Lunniss PJ. Linear discriminant analysis of symptoms in patients with chronic constipation: validation of a new scoring system (KESS). Dis Colon Rectum. 2000;43:1419-26.

43. Rockwood TH, Church JM, Fleshman JW, Kane RL, Mavrantonis C, Thorson AG, et al. Fecal Incontinence Quality-of-life Scale: quality-of life instrument for patients with fecal incontinence. Dis Colon Rectum. 2000;43:9-16.

44. Anaf V, Simon Ph, Fayt I, Noel JC. Smooth muscles are frequent components of endometriotic lesions. Hum Reprod. 2000;15;767-71.

45. Noël JC, Chapron C, Bucella D, Buxant F, Peny MO, Fayt I, et al. Estrogen and progesterone receptors in smooth muscle component of deep infiltrating endometriosis. Fertil Steril. 2010;93:1774-7.

46. Casper RF. Progestin-only pills may be a better first-line treatment for endometriosis than combined estrogen-progestin contraceptive pills. Fertil Steril. 2017; 107:568-70.

47. Vigano P, Candiani M, Monno A, Giacomini E, Vercellini P, Somigliana E. Time to redefine endometriosis including its pro-fibrotic nature. Hum Reprod. 2017:1-6. doi: 10.1093/humrep/dex354. [Epub ahead of print]

48. Riiskjær M, Egekvist AG, Hartwell D, Forman A, Seyer-Hansen M, Kesmodel US. Bowel endometriosis syndrome: a new scoring system for pelvic organ dysfunction and quality of life. Hum Reprod. 2017;32:1812-1818.

This article is protected by copyright. All rights reserved. 
49. Vercellini P, Somigliana E, Cortinovis I, Bracco B, de Braud L, Dridi D, et al. "You can't always get what you want": from doctrine to practicability of study designs for clinical investigation in endometriosis. BMC Womens Health. 2015;15:89.

50. Fedele L, Berlanda N, Corsi C, Gazzano G, Morini M, Vercellini P. Ileocecal endometriosis: clinical and pathogenetic implications of an underdiagnosed condition. Fertil Steril. 2014;101:750-3.

51. Barbosa RN, Andres MP, Kho RM, Abrão MS. Ileum endometriosis: a cause of bowel obstruction. J Minim Invasive Gynecol. 2017; pii: S1553-4650(17)31224-4.

52. Riiskjaer M, Greisen S, Glavind-Kristensen M, Kesmodel US, Forman A, Seyer-Hansen M. Pelvic organ function before and after laparoscopic bowel resection for rectosigmoid endometriosis: a prospective, observational study. BJOG. 2016; 123:1360-7.

53. Setúbal A, Sidiropoulou Z, Torgal M, Casal E, Lourenço C, Koninckx P. Bowel complications of deep endometriosis during pregnancy or in vitro fertilization. Fertil Steril. 2014;101:442-6.

54. Roman H, Puscasiu L, Lempicki M, Huet E, Chati R, Bridoux V, et al. Colorectal endometriosis responsible for bowel occlusion or subocclusion in women with pregnancy intention: is the policy of primary in vitro fertilization always safe? J Minim Invasive Gynecol. 2015;22:1059-67.

55. Seyer-Hansen M, Egekvist A, Forman A, Riiskjaer M. Risk of bowel obstruction during in vitro fertilization treatment of patients with deep infiltrating endometriosis. Acta Obstet Gynecol Scand. 2018;97:47-52.

56. Anaf V, El Nakadi I, Simon P, Englert $Y$, Peny MO, Fayt I, et al. Sigmoid endometriosis and ovarian stimulation. Hum Reprod. 2000;15:790-4.

57. Roman H. Colorectal endometriosis and pregnancy wish: why doing primary surgery. Front Biosci (Schol Ed). 2015; 7: 83-93.

58. Thomin A, Belghiti J, David C, Marty O, Bornes M, Ballester M, et al. Maternal and neonatal outcomes in women with colorectal endometriosis. BJOG. 2016. doi: 10.1111/1471-0528.14221. [Epub ahead of print].

59. Vercellini P, Frattaruolo MP, Barbara G, Buggio L, Somigliana E. The ominous association between severe endometriosis, in vitro fertilisation, and placenta previa: raising awareness, limiting risks, informing women. BJOG. 2018; 125:12-15.

This article is protected by copyright. All rights reserved. 
60. Berlanda N, Somigliana E, Frattaruolo MP, Buggio L, Dridi D, Vercellini P. Surgery versus hormonal therapy for deep endometriosis: is it a choice of the physician? Eur J Obstet Gynecol Reprod Biol. 2017;209:67-71.

FIGURE LEGENDS

Table 1. Effect of aromatase inhibitors, estrogen-progestins, gonadotropin releasing hormone agonists $(\mathrm{GnRHa})$ and progestins as assessed in studies on the treatment of bowel endometriosis (literature data, 2000-2018) ${ }^{\mathrm{a}}$.

Figure 1. Double-contrast barium enema showing an endometriotic stenosis of the rectosigmoid junction (arrows).

Figure 2. Colonoscopy showing an endometriotic nodule infiltrating the sigmoid wall and protruding into the bowel lumen.

Figure 3. Suggested algorithm for a symptom-based management of large bowel endometriosis in women not seeking a natural conception. US = ultrasonography; $\mathrm{MRI}=$ magnetic resonance imagining; $\mathrm{CT}$ = computed tomography; $\mathrm{GI}$ = gastrointestinal

This article is protected by copyright. All rights reserved. 
Table 1. Effect of aromatase inhibitors, estrogen-progestins, gonadotropin releasing hormone agonists (GnRHa) and progestins as assessed in studies on the treatment of bowel endometriosis (literature data, 2000-2018) ${ }^{\text {a }}$

\begin{tabular}{|c|c|c|c|c|c|c|c|c|}
\hline Source & Study design & $\begin{array}{l}\text { Patients } \\
\text { enrolled } \\
(n)\end{array}$ & $\begin{array}{l}\text { Location of } \\
\text { bowel } \\
\text { endometriotic } \\
\text { nodules }\end{array}$ & Study drug & $\begin{array}{l}\text { Treatment } \\
\text { period }\end{array}$ & $\begin{array}{l}\text { Adverse effects } \\
(\%)\end{array}$ & $\begin{array}{l}\text { Questionnaires } \\
\text { adopted to } \\
\text { evaluate bowel } \\
\text { symptoms }\end{array}$ & Outcome \\
\hline $\begin{array}{l}\text { Porpora } e t \\
\text { al., } 2006 \\
(36)\end{array}$ & Case report & 1 & Sigmoid lesion & $\begin{array}{l}\text { Leuprolide } \\
\text { acetate } 3.75 \\
\text { mg/28 days i.m. }\end{array}$ & 3 months & NR & NR & $\begin{array}{l}\text { Disappearance of } \\
\text { symptoms after the } \\
\text { first injection. At 6- } \\
\text { months follow-up } \\
\text { colonoscopy } \\
\text { disappearance of } \\
\text { bowel lesion. No } \\
\text { recurrence of bowel } \\
\text { lesion at follow-up } \\
\text { colonoscopy } \\
\text { (performed every year } \\
\text { for } 2 \text { years) }\end{array}$ \\
\hline $\begin{array}{l}\text { Ferrero et } \\
a l ., 2010 \\
(10)\end{array}$ & $\begin{array}{l}\text { Prospective } \\
\text { case series }\end{array}$ & 18 & $\begin{array}{l}\text { Proximal rectum } \\
(n=4) ; \\
\text { rectosigmoid } \\
\text { junction }(n=5) ; \\
\text { sigmoid lesion }(n \\
=9)\end{array}$ & $\begin{array}{l}\text { Triptorelin } 11.25 \\
\mathrm{mg} / 3 \text { months } \\
\text { i.m. + tibolone } \\
2.5 \mathrm{mg} / \text { day per } \\
\text { os }\end{array}$ & 12 months & $\begin{array}{l}\text { Hot flushes (33) } \\
\text { Vaginal bleeding } \\
\text { (33) } \\
\text { Sweating episodes } \\
\text { (17) } \\
\text { Vaginal dryness } \\
\text { and superficial } \\
\text { dyspareunia (11) } \\
\text { Nervousness and }\end{array}$ & $\begin{array}{l}\text { Patient self } \\
\text { judgements of } \\
\text { changes in } \\
\text { gastrointestinal } \\
\text { symptoms using } \\
\text { a 5-point Likert } \\
\text { scale } \\
\text { (significantly } \\
\text { improved, } \\
\text { improved, } \\
\text { unchanged, }\end{array}$ & $\begin{array}{l}\text { Significant } \\
\text { improvement of pain } \\
\text { symptoms. } \\
\text { Improvement in } \\
\text { intestinal function in } \\
\text { patients with } \\
\text { symptoms mimicking } \\
\text { IBS-D. At 12-month } \\
\text { assessment } 13(72 \%) \\
\text { women were very } \\
\text { satisfied or satisfied, } 2\end{array}$ \\
\hline
\end{tabular}

This article is protected by copyright. All rights reserved. 


\begin{tabular}{|c|c|c|c|c|c|c|c|c|}
\hline Source & Study design & $\begin{array}{l}\text { Patients } \\
\text { enrolled } \\
(n)\end{array}$ & $\begin{array}{l}\text { Location of } \\
\text { bowel } \\
\text { endometriotic } \\
\text { nodules }\end{array}$ & Study drug & $\begin{array}{l}\text { Treatment } \\
\text { period }\end{array}$ & $\begin{array}{l}\text { Adverse effects } \\
(\%)\end{array}$ & $\begin{array}{l}\text { Questionnaires } \\
\text { adopted to } \\
\text { evaluate bowel } \\
\text { symptoms }\end{array}$ & Outcome \\
\hline & & & & & & $\begin{array}{l}\text { irritability (11) } \\
\text { Weight gain (11) } \\
\text { Sleeplessness (6) } \\
\text { Fatigue (6) } \\
\text { Difficulty in } \\
\text { concentration (6) }\end{array}$ & $\begin{array}{l}\text { worsened, } \\
\text { significantly } \\
\text { worsened) }\end{array}$ & $\begin{array}{l}(11 \%) \text { were uncertain, } \\
\text { and } 3(17 \%) \text { were } \\
\text { dissatisfied }\end{array}$ \\
\hline $\begin{array}{l}\text { Ferrero } \text { et } \\
\text { al., } 2010 \\
(11)\end{array}$ & $\begin{array}{l}\text { Prospective } \\
\text { case series }\end{array}$ & 40 & $\begin{array}{l}\text { Proximal rectum } \\
(n=10) ; \\
\text { rectosigmoid } \\
\text { junction }(n=12) ; \\
\text { sigmoid lesion }(n \\
=18)\end{array}$ & $\begin{array}{l}\text { NETA } 2.5 \\
\text { mg/day per os }\end{array}$ & 12 months & $\begin{array}{l}\text { Worsening of } \\
\text { constipation (7.5) } \\
\text { Breakthrough } \\
\text { bleeding (5) } \\
\text { Weight gain (5) } \\
\text { Spotting (2.5) } \\
\text { Depression (2.5) } \\
\text { Migraine attacks } \\
(2.5)\end{array}$ & $\begin{array}{l}\text { Symptom } \\
\text { analogue scale } \\
\text { questionnaire (1 } \\
\text { indicated the } \\
\text { absence of the } \\
\text { symptom; } 10 \\
\text { indicated the } \\
\text { highest severity } \\
\text { of the symptom) } \\
\text { regarding each } \\
\text { gastrointestinal } \\
\text { symptom. }\end{array}$ & $\begin{array}{l}\text { Significant } \\
\text { improvement of dysm, } \\
\text { dysp, CPP, dyschezia } \\
\text { and diarrhea. No } \\
\text { significant } \\
\text { improvement in } \\
\text { patients with } \\
\text { constipation, } \\
\text { abdominal bloating } \\
\text { and feeling of } \\
\text { incomplete evacuation } \\
\text { after bowel } \\
\text { movements. } 60 \% \text { of } \\
\text { patients were satisfied } \\
\text { or very satisfied with } \\
\text { the treatment. }\end{array}$ \\
\hline
\end{tabular}

This article is protected by copyright. All rights reserved. 


\begin{tabular}{|c|c|c|c|c|c|c|c|c|}
\hline Source & Study design & $\begin{array}{l}\text { Patients } \\
\text { enrolled } \\
(n)\end{array}$ & $\begin{array}{l}\text { Location of } \\
\text { bowel } \\
\text { endometriotic } \\
\text { nodules }\end{array}$ & Study drug & $\begin{array}{l}\text { Treatment } \\
\text { period }\end{array}$ & \begin{tabular}{|l} 
Adverse effects \\
$(\%)$
\end{tabular} & $\begin{array}{l}\text { Questionnaires } \\
\text { adopted to } \\
\text { evaluate bowel } \\
\text { symptoms }\end{array}$ & Outcome \\
\hline $\begin{array}{l}\text { Ferrero et } \\
\text { al., } 2010 \\
(32)\end{array}$ & $\begin{array}{l}\text { Prospective } \\
\text { case series }\end{array}$ & 6 & $\begin{array}{l}\text { Proximal rectum } \\
(n=2) ; \\
\text { rectosigmoid } \\
\text { junction }(n=2) ; \\
\text { sigmoid lesion }(n \\
=2)\end{array}$ & $\begin{array}{l}\text { Letrozole } 2.5 \\
\mathrm{mg} / \text { day + NETA } \\
2.5 \mathrm{mg} / \text { day per } \\
\text { os }\end{array}$ & 6 months & $\begin{array}{l}\text { Breakthrough } \\
\text { bleeding (17) } \\
\text { Weight gain (17) } \\
\text { Joint pain (17) } \\
\text { Decreased libido } \\
(17)\end{array}$ & $\begin{array}{l}\text { Symptom } \\
\text { analogue scale } \\
\text { questionnaire (1 } \\
\text { indicated the } \\
\text { absence of the } \\
\text { symptom; } 10 \\
\text { indicated the } \\
\text { highest severity } \\
\text { of the symptom) } \\
\text { regarding each } \\
\text { gastrointestinal } \\
\text { symptom. }\end{array}$ & $\begin{array}{l}\text { Significant } \\
\text { improvement of dysm, } \\
\text { dysp, CPP, and } \\
\text { gastrointestinal } \\
\text { symptoms. } \\
\text { High satisfaction rate } \\
\text { at the end of study } \\
\text { period (67\% of } \\
\text { women were satisfied } \\
\text { or very satisfied). } \\
\text { No changes in BMD } \\
\text { were identified. }\end{array}$ \\
\hline $\begin{array}{l}\text { Harada } e t \\
\text { al., } 2011 \\
(33)\end{array}$ & $\begin{array}{l}\text { Retrospective } \\
\text { case series }\end{array}$ & 4 & $\begin{array}{l}\text { Rectosigmoid } \\
\text { junction }(n=4)\end{array}$ & $\begin{array}{l}\text { DNG } 2 \mathrm{mg} / \text { day } \\
\text { per os }\end{array}$ & 12 months & \begin{tabular}{|l|} 
Spotting (75) \\
Hot Flushes (50) \\
Gastralgia (25) \\
Depression (25)
\end{tabular} & $\mathrm{NR}$ & $\begin{array}{l}\text { Significant } \\
\text { improvement of pain } \\
\text { symptoms and } \\
\text { reduction in nodule } \\
\text { size. }\end{array}$ \\
\hline $\begin{array}{l}\text { Ferrari et } \\
\text { al., } 2012 \\
(12)\end{array}$ & $\begin{array}{l}\text { Prospective } \\
\text { case series }\end{array}$ & $22^{\mathrm{c}}$ & $\begin{array}{l}\text { Proximal rectum, } \\
n=14 ; \text { recto- } \\
\text { sigmoid } \\
\text { junction/sigmoid, } \\
n=8\end{array}$ & $\begin{array}{l}\text { Continuous low- } \\
\text { dose } \\
\text { monophasic OC } \\
(\text { EE } 15 \mu \mathrm{g}+ \\
\text { gestodene } 60 \\
\mu \mathrm{g}) / \text { day }\end{array}$ & 12 months & $\begin{array}{l}\text { Breakthrough } \\
\text { bleeding (38) } \\
\text { Weight gain (23) } \\
\text { Headache (12) } \\
\text { Decreased libido } \\
(8)\end{array}$ & $\begin{array}{l}\text { Dyschezia was } \\
\text { assessed by } 0-10 \\
\text { visual analog } \\
\text { pain scale }(0 \\
\text { indicated the } \\
\text { absence of the } \\
\text { symptom; } 10 \\
\text { indicated the }\end{array}$ & $\begin{array}{l}\text { Significant } \\
\text { improvement of dysm, } \\
\text { dysp, CPP, and } \\
\text { dyschezia. } \\
\text { Significant reduction } \\
\text { of nodule size after } 12 \\
\text { months of treatment. }\end{array}$ \\
\hline
\end{tabular}

This article is protected by copyright. All rights reserved. 


\begin{tabular}{|c|c|c|c|c|c|c|c|c|}
\hline Source & Study design & $\begin{array}{l}\text { Patients } \\
\text { enrolled } \\
(n)\end{array}$ & $\begin{array}{l}\text { Location of } \\
\text { bowel } \\
\text { endometriotic } \\
\text { nodules }\end{array}$ & Study drug & $\begin{array}{l}\text { Treatment } \\
\text { period }\end{array}$ & $\begin{array}{l}\text { Adverse effects } \\
(\%)\end{array}$ & $\begin{array}{l}\text { Questionnaires } \\
\text { adopted to } \\
\text { evaluate bowel } \\
\text { symptoms }\end{array}$ & Outcome \\
\hline & & & & & & & $\begin{array}{l}\text { highest severity } \\
\text { of the symptom) }\end{array}$ & $\begin{array}{l}\text { High satisfaction rate } \\
\text { at the end of study } \\
\text { period ( } 69 \% \text { of } \\
\text { women were satisfied } \\
\text { or very satisfied). }\end{array}$ \\
\hline $\begin{array}{l}\text { Tamura et } \\
\text { al., } 2013 \\
(37)\end{array}$ & Case report & 1 & $\begin{array}{l}\text { Proximal rectum } \\
\text { and rectosigmoid } \\
\text { junction }\end{array}$ & $\begin{array}{l}\text { Cyclic DNG } 2 \\
\text { mg/day per os }\end{array}$ & 22 months & Spotting & NR & $\begin{array}{l}\text { Significant } \\
\text { improvement of pain } \\
\text { and gastrointestinal } \\
\text { symptoms. } \\
\text { Disappearance of } \\
\text { bowel lesion at } \\
\text { biopsy. Reduction of } \\
\text { CA-125 serum levels. }\end{array}$ \\
\hline $\begin{array}{l}\text { Roman et } \\
\text { al., } 2015 \\
(34)\end{array}$ & $\begin{array}{l}\text { Prospective } \\
\text { case series }\end{array}$ & 70 & $\begin{array}{l}\text { Lesions located } \\
\text { within } 15 \mathrm{~cm} \\
\text { from the anal } \\
\text { verge. }\end{array}$ & $\begin{array}{l}\text { Triptorelin } \\
\text { acetate } 11.25 \mathrm{mg} \\
\text { i.m. + estradiol } \\
0.1 \% / \text { day } \\
\text { percutaneous }\end{array}$ & $\begin{array}{l}3.4 \pm 1.8 \\
\text { months }\end{array}$ & NR & $\begin{array}{l}\text { GIQLI (ref. 40), } \\
\text { Bristol stool } \\
\text { scale (ref. 41), } \\
\text { KESS (ref. 42), } \\
\text { Fecal } \\
\text { Incontinence } \\
\text { Quality of Life } \\
\text { index (ref. 43) }\end{array}$ & $\begin{array}{l}\text { Improvement of cyclic } \\
\text { digestive complaints } \\
\text { in more than half of } \\
\text { patients. Constipation } \\
\text { and non-cyclic } \\
\text { symptoms were } \\
\text { improved in in less } \\
\text { than a third of } \\
\text { patients. }\end{array}$ \\
\hline $\begin{array}{l}\text { Yela et al., } \\
2015 \text { (13) }\end{array}$ & $\begin{array}{l}\text { Prospective } \\
\text { case series }\end{array}$ & 16 & Not specified & $\begin{array}{l}\text { DNG } 2 \mathrm{mg} / \text { day } \\
\text { per os }\end{array}$ & 6 months & $\begin{array}{l}\text { Headache } \\
\text { Acne }\end{array}$ & $\begin{array}{l}\text { Dyschezia was } \\
\text { assessed by } 0-10 \\
\text { visual analog } \\
\text { pain scale }(0\end{array}$ & $\begin{array}{l}\text { Significant } \\
\text { improvement of pain } \\
\text { symptoms (dysm, } \\
\text { dysp, CPP, and }\end{array}$ \\
\hline
\end{tabular}

This article is protected by copyright. All rights reserved. 


\begin{tabular}{|c|c|c|c|c|c|c|c|c|}
\hline Source & Study design & $\begin{array}{l}\text { Patients } \\
\text { enrolled } \\
(n)\end{array}$ & $\begin{array}{l}\text { Location of } \\
\text { bowel } \\
\text { endometriotic } \\
\text { nodules }\end{array}$ & Study drug & $\begin{array}{l}\text { Treatment } \\
\text { period }\end{array}$ & $\begin{array}{l}\text { Adverse effects } \\
(\%)\end{array}$ & $\begin{array}{l}\text { Questionnaires } \\
\text { adopted to } \\
\text { evaluate bowel } \\
\text { symptoms }\end{array}$ & Outcome \\
\hline & & & & & & $\begin{array}{l}\text { Decreased libido } \\
\text { Breast pain } \\
\text { Hair loss } \\
\text { Nausea/vomit } \\
\text { Bloating } \\
\text { Vaginal dryness }\end{array}$ & $\begin{array}{l}\text { indicated the } \\
\text { absence of the } \\
\text { symptom; } 10 \\
\text { indicated the } \\
\text { highest severity } \\
\text { of the symptom) }\end{array}$ & $\begin{array}{l}\text { dyschezia). No } \\
\text { significant changes in } \\
\text { volume size of } \\
\text { endometriotic nodules. } \\
\text { No significant changes } \\
\text { in QoL and sexual } \\
\text { function. }\end{array}$ \\
\hline $\begin{array}{l}\text { Millochau et } \\
\text { al., } 2016 \\
(38)\end{array}$ & Case report & 1 & Sigmoid colon & $\begin{array}{l}\text { Cyproterone } \\
\text { acetate } 50 \\
\mathrm{mg} / \text { day per os }+ \\
\text { Estradiol } 0.5 \\
\mathrm{mg} / \text { day } \\
\text { percutaneous gel } \\
\text { (first } 2 \text { years) } \\
\text { Continuous } \\
\text { medium dose } \\
\text { OC (EE } 30 \mu \mathrm{g}+ \\
\mathrm{LNG} 150 \\
\mu \mathrm{g} \text { )/day } \\
\text { (until the end of } \\
\text { follow-up) }\end{array}$ & 4 years & $\begin{array}{l}\text { With cyproterone } \\
\text { acetate: } \\
\text { Mood changes }\end{array}$ & $\begin{array}{l}\text { GIQLI (ref.40), } \\
\text { KESS (ref.42) }\end{array}$ & $\begin{array}{l}\text { With cyproterone } \\
\text { acetate partial } \\
\text { amelioration of } \\
\text { gastrointestinal } \\
\text { symptoms, with } \\
\text { unchanged } \\
\text { constipation and } \\
\text { bloating. } \\
\text { With OC worsening of } \\
\text { gastrointestinal } \\
\text { symptoms and } \\
\text { enlargement of bowel } \\
\text { nodule at MRI and } \\
\text { CT-based virtual } \\
\text { colonoscopy. }\end{array}$ \\
\hline
\end{tabular}

This article is protected by copyright. All rights reserved. 


\begin{tabular}{|c|c|c|c|c|c|c|c|c|}
\hline Source & \begin{tabular}{|l|} 
Study design \\
\end{tabular} & $\begin{array}{l}\text { Patients } \\
\text { enrolled } \\
(n)\end{array}$ & $\begin{array}{l}\text { Location of } \\
\text { bowel } \\
\text { endometriotic } \\
\text { nodules }\end{array}$ & Study drug & $\begin{array}{l}\text { Treatment } \\
\text { period }\end{array}$ & $\begin{array}{l}\text { Adverse effects } \\
(\%)\end{array}$ & $\begin{array}{l}\text { Questionnaires } \\
\text { adopted to } \\
\text { evaluate bowel } \\
\text { symptoms }\end{array}$ & Outcome \\
\hline $\begin{array}{l}\text { Leonardo- } \\
\text { Pinto et al., } \\
2017 \text { (14) }\end{array}$ & $\begin{array}{l}\text { Prospective } \\
\text { case series }\end{array}$ & 30 & Not specified & $\begin{array}{l}\text { DNG } 2 \mathrm{mg} / \text { day } \\
\text { per os }\end{array}$ & 12 months & $\begin{array}{l}\text { Headache (63) } \\
\text { Breast pain (43) } \\
\text { Decreased libido } \\
(43) \\
\text { Nausea/vomiting } \\
(23)\end{array}$ & $\begin{array}{l}\text { Intestinal pain } \\
\text { was assessed by } \\
0-10 \text { visual } \\
\text { analog pain scale } \\
\text { ( } 0 \text { indicated the } \\
\text { absence of the } \\
\text { symptom; } 10 \\
\text { indicated the } \\
\text { highest severity } \\
\text { of the symptom) }\end{array}$ & $\begin{array}{l}\text { Significant } \\
\text { improvement of pain } \\
\text { symptoms (dysm, } \\
\text { dysp, CPP, bowel } \\
\text { pain) and QoL. No } \\
\text { significant changes in } \\
\text { volume size of } \\
\text { endometriotic nodules. }\end{array}$ \\
\hline $\begin{array}{l}\text { Ng et al., } \\
2017 \text { (39) }\end{array}$ & Case report & 1 & $\begin{array}{l}\text { Proximal rectum } \\
\text { and rectosigmoid } \\
\text { junction }\end{array}$ & $\begin{array}{l}\text { DNG } 2 \mathrm{mg} / \text { day } \\
\text { per os }\end{array}$ & 6 months & Spotting & NR & $\begin{array}{l}\text { Significant } \\
\text { improvement of pain } \\
\text { (dysm, dysp) and } \\
\text { gastrointestinal } \\
\text { symptoms. }\end{array}$ \\
\hline $\begin{array}{l}\text { Vercellini et } \\
\text { al., } 2017 \\
(29)\end{array}$ & \begin{tabular}{|l|} 
Retrospective \\
cohort study
\end{tabular} & $50^{d}$ & $\begin{array}{l}\text { Proximal rectum, } \\
\text { rectosigmoid } \\
\text { junction, and } \\
\text { sigmoid colon }\end{array}$ & 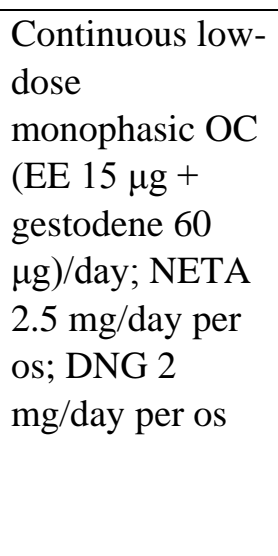 & $\begin{array}{l}40[18-60] \\
\text { months }\end{array}$ & $\begin{array}{l}\text { Weight gain (32), } \\
\text { decreased libido } \\
\text { (18), bloating (16), } \\
\text { vaginal dryness } \\
\text { (16), headache (10), } \\
\text { and mood changes } \\
(4)\end{array}$ & $\begin{array}{l}\text { KESS; } \\
\text { Intestinal } \\
\text { symptoms were } \\
\text { assessed by } 0-10 \\
\text { numerical rating } \\
\text { scale scale }(0 \\
\text { indicated the } \\
\text { absence of the } \\
\text { symptom; } 10 \\
\text { indicated the } \\
\text { highest severity }\end{array}$ & $\begin{array}{l}\text { At final follow-up, } 14 \\
\text { patients were very } \\
\text { satisfied, } 22 \text { satisfied, } \\
5 \text { neither satisfied nor } \\
\text { dissatisfied, } 7 \\
\text { dissatisfied, and } 2 \\
\text { very dissatisfied. } \\
\text { Significant } \\
\text { improvements of } \\
\text { bowel symptoms as } \\
\text { assessed by both the }\end{array}$ \\
\hline
\end{tabular}

This article is protected by copyright. All rights reserved. 


\begin{tabular}{|c|c|c|c|c|c|c|c|c|}
\hline Source & Study design & $\begin{array}{l}\text { Patients } \\
\text { enrolled } \\
(n)\end{array}$ & $\begin{array}{l}\text { Location of } \\
\text { bowel } \\
\text { endometriotic } \\
\text { nodules }\end{array}$ & Study drug & $\begin{array}{l}\text { Treatment } \\
\text { period }\end{array}$ & $\begin{array}{l}\text { Adverse effects } \\
(\%)\end{array}$ & $\begin{array}{l}\text { Questionnaires } \\
\text { adopted to } \\
\text { evaluate bowel } \\
\text { symptoms }\end{array}$ & Outcome \\
\hline & & & & & & & of the symptom) & $\begin{array}{l}\text { KESS questionnaire } \\
\text { and the numerical } \\
\text { rating scale. }\end{array}$ \\
\hline
\end{tabular}

${ }^{a}$ Egekvist et al., 2017 (35) was not included in the table because the exact number of patients who used the different medical treatments (OC, LNGintrauterine

device or oral progestins), the adverse effects associated with their use, and the different outcomes in terms of pain symptoms or gastrointestinal symptoms variation could not be extracted from the published report.

${ }^{\mathrm{b}}$ In case of breakthrough bleeding the daily oral dose of NETA was doubled.

${ }^{\mathrm{c}}$ Patients with medium-low rectum nodules $(n=4)$ are excluded.

${ }^{\mathrm{d}}$ Only patients who chose medical treatment are here reported.

$\mathrm{BMD}=$ bone mineral density $; \mathrm{CPP}=$ chronic pelvic pain $; \mathrm{DNG}=$ dienogest dysm = dysmenorrhea dysp = dyspareunia $; \mathrm{EE}=$ ethinyl-estradiol; $\mathrm{GIQLI}=$

Gastro Intestinal Quality of Life Index; IBS-D = diarrhea-predominant irritable bowel syndrome; KESS = Knowles-Eccersley-Scott-Symptom Questionnaire; $\mathrm{LNG}=$ levonorgestrel; $\mathrm{MRI}=$ magnetic resonance image; NETA = nor-ethisterone acetate; NA = not applicable; $\mathrm{NR}=$ not reported; OC $=$ oral contraceptive

This article is protected by copyright. All rights reserved. 


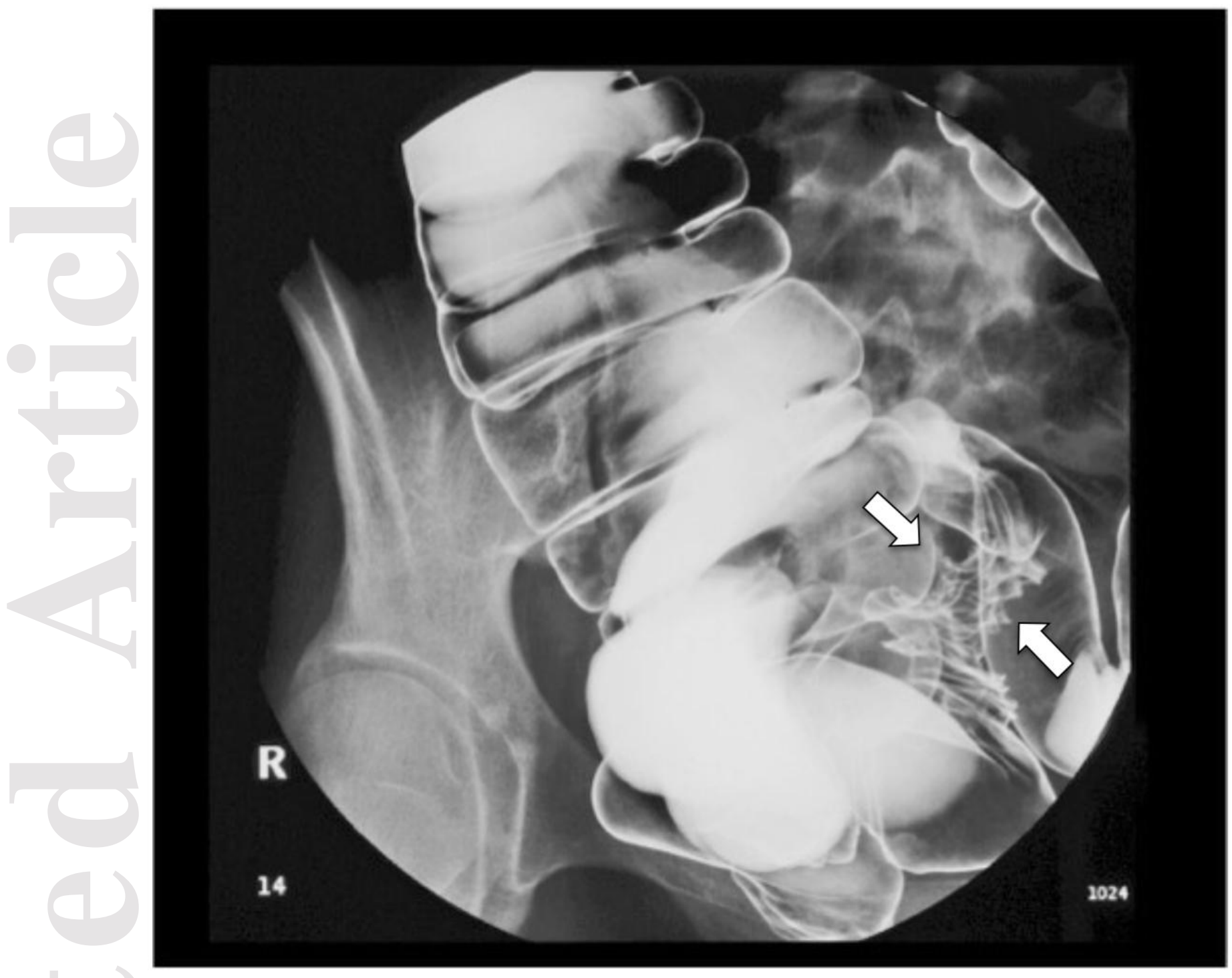

This article is protected by copyright. All rights reserved. 


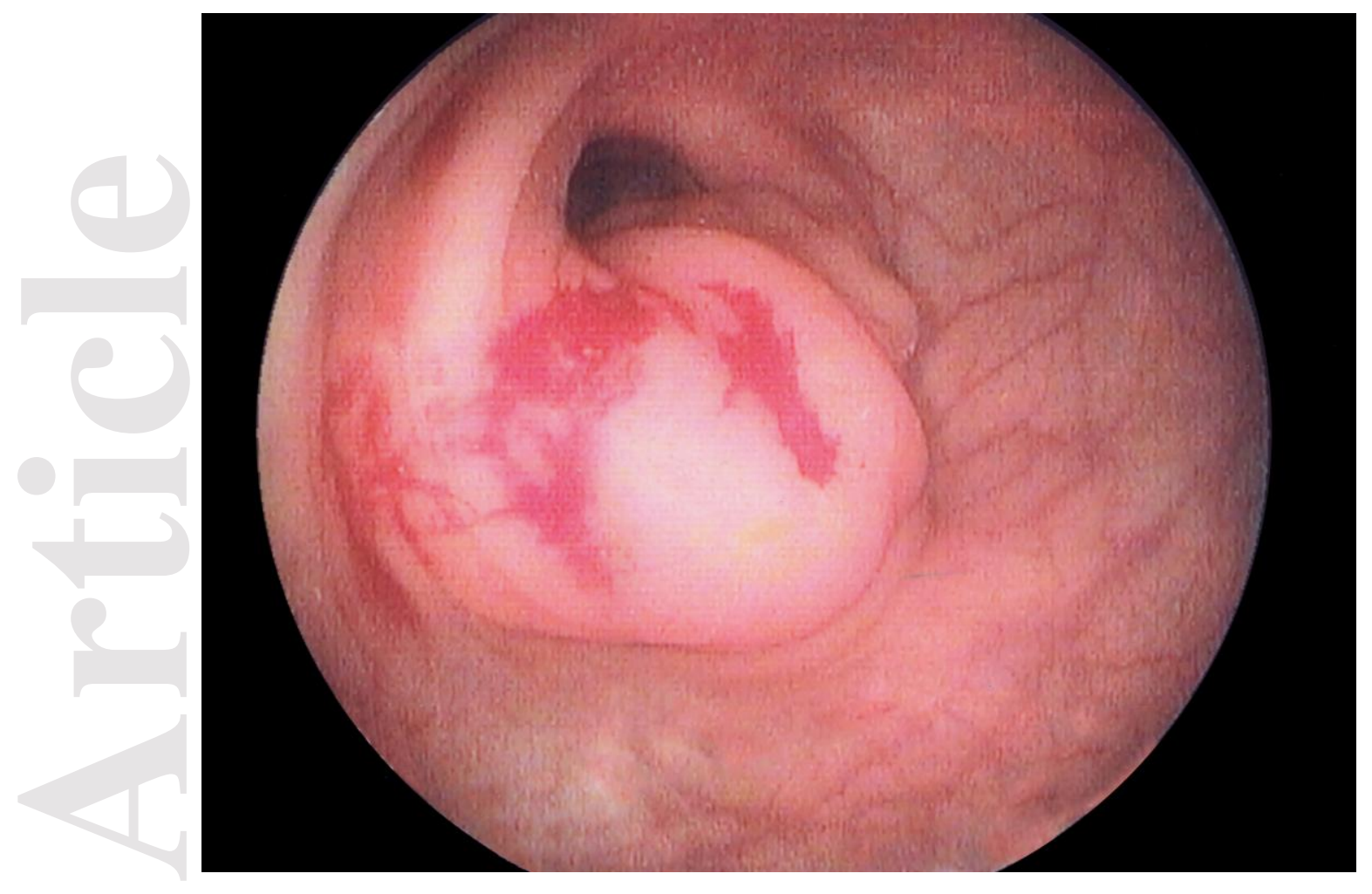

This article is protected by copyright. All rights reserved. 
Imaging techniques (US; barium enema; MRI;

CT colonography) and rectosigmoidoscopy or colonoscopy demonstrating endometriosis deeply infiltrating the rectosigmoid

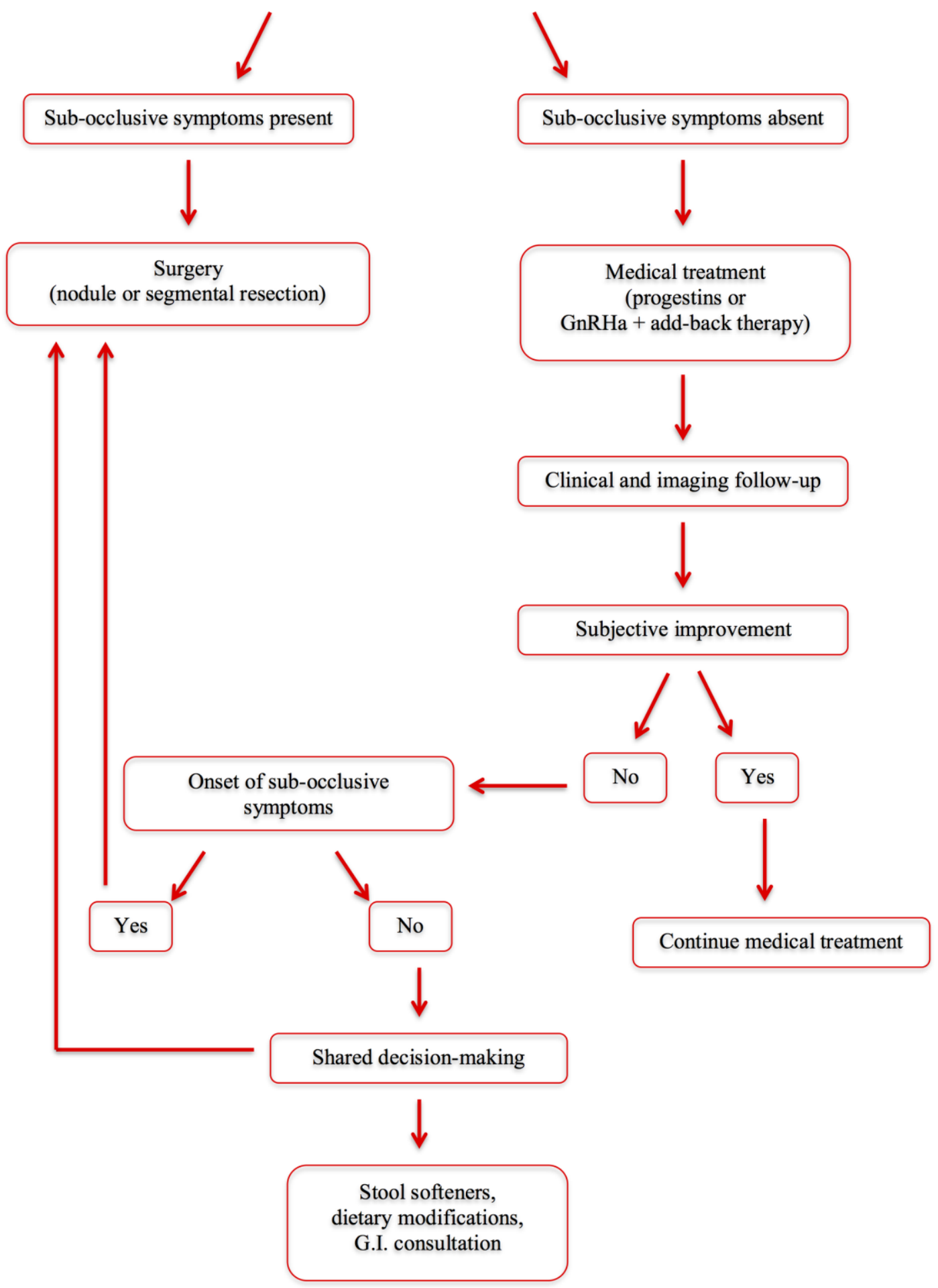

This article is protected by copyright. All rights reserved. 